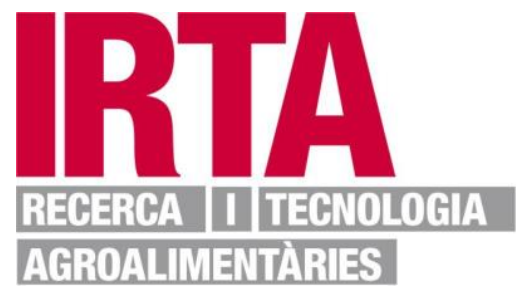

This document is a postprint version of an article published in Food Research International@ Elsevier after peer review. To access the final edited and published work see https://doi.org/10.1016/i.foodres.2019.108578

Document downloaded from:

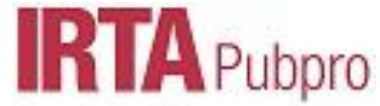

Open dgital archeve 


\section{Accepted Manuscript}

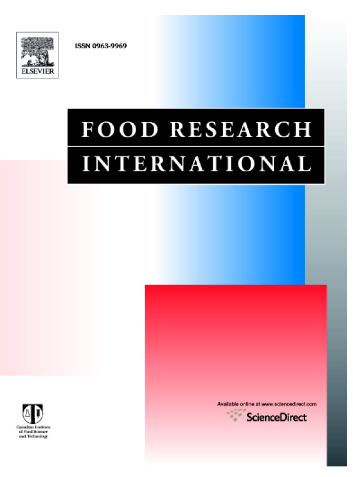

Anna Jofré, Mari Luz Latorre-Moratalla, Margarita Garriga, Sara Bover-Cid

PII:

S0963-9969(19)30456-9

DOI:

https://doi.org/10.1016/j.foodres.2019.108578

Article Number:

108578

Reference:

FRIN 108578

To appear in:

\section{Food Research International}

Received date: $\quad 6$ February 2019

Revised date: $\quad 19$ July 2019

Accepted date: $\quad 21$ July 2019

Please cite this article as: A. Jofré, M.L. Latorre-Moratalla, M. Garriga, et al., Domestic refrigerator temperatures in Spain: Assessment of its impact on the safety and shelflife of cooked meat products, Food Research International, https://doi.org/10.1016/ j.foodres.2019.108578

This is a PDF file of an unedited manuscript that has been accepted for publication. As a service to our customers we are providing this early version of the manuscript. The manuscript will undergo copyediting, typesetting, and review of the resulting proof before it is published in its final form. Please note that during the production process errors may be discovered which could affect the content, and all legal disclaimers that apply to the journal pertain. 


\title{
Domestic refrigerator temperatures in Spain: assessment of its impact on the safety and shelf-life of cooked meat products
}

\author{
Anna Jofréa ${ }^{a}$ Mari Luz Latorre-Moratallab, Margarita Garriga ${ }^{\mathrm{a}}$ and Sara Bover-Cid ${ }^{\mathrm{a},{ }^{*}}$ \\ sara.bovercid@irta.cat
}

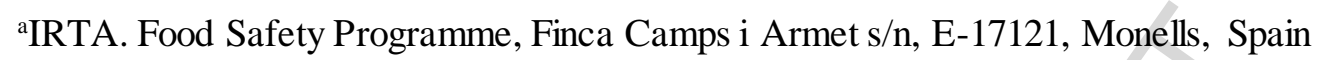
${ }^{b}$ Department of Nutrition, Food Sciences and Gastronomy, XaRTA, INSA, School of Pharmacy and Food Sciences, University of Barcelona, Avinguda Prat de la Riba, 171; E-08921 Santa Coloma de Gramenet, Spain

${ }^{*}$ Corresponding author.

\section{Abstract}

Temperature is one of the main factors governing the growth of microorganisms. The aim of the present study was to provide temperature conditions representative of the food products stored in domestic refrigerators and to assess the impact of the temperature (fluctuation) on the shelflife of refrigerated cooked meat products, from the safety and the spoilage point of view. The analysis of the time-temperature profiles recorded from 160 domestic refrigerators of households from small (28\%) and large (72\%) municipalities in Catalonia (Spain) showed that the $24 \mathrm{~h}$-registers mean temperature could be described by a normal distribution (mean $=5.4^{\circ} \mathrm{C}$, standard deviation $=2.3^{\circ} \mathrm{C}$ ) with a mean value within the upper limit of the appropriate storage temperature of refrigerated products (i.e. $\leq 6^{\circ} \mathrm{C}$ ). The impact of door openings or day and night was not significant. Temperature distribution showed differences depending on the season, being higher in the cold season than in the warm one. Noteworthy, refrigerators of elderly $(\geq 65$ years old) household showed a higher percentage of time at temperatures $>8^{\circ} \mathrm{C}$ in comparison with those of the general population. Overall, the $75^{\text {th }}$ percentile of the distribution of the $24 \mathrm{~h}$ mean temperature values was $6.7^{\circ} \mathrm{C}$. This study can be used as a scientific evidence of the consumer storage stage when food business operators or laboratories conduct shelf-life studies. According to the simulation of the growth of Listeria monocytogenes and lactic acid bacteria in cooked meat products, risk scenarios were identified in which the critical level of the pathogen could be reached before lactic acid bacteria achieved the spoilage level. The fluctuation of the refrigerator temperature ranged from 0.5 up to $12.2^{\circ} \mathrm{C}$ within the $24 \mathrm{~h}$-profile. The assessment of the safety of cooked meat products stored at constant temperature or under different timetemperature profiles showed that both the mean and the fluctuation of the profile had an impact 
on the shelf-life, which was higher at low temperatures. The improvement of the household refrigerated storage would be an effective way to increase food safety of refrigerated ready-toeat food.

\section{Keywords}

Consumer survey; cold-chain; food safety; fridge; L. monocytogenes; risk assessment; ready-toeat; predictive microbiology 


\section{Introduction}

The control of the time and temperature along the food cold chain (from producer to consumer) is of paramount importance for maintaining the safety and quality of perishable food products because temperature is one of the main factors governing the growth of microorganisms. Within the cold chain maintenance, the first steps (i.e. processing and distribution) are under the responsibility of the food business operator (FBO) and are in most cases reasonably well controlled (EFSA, 2008). During the subsequent household storage, in which products may spend a considerable part of their shelf-life, the temperature control depends on the diligence of the consumers. Home storage is probably one of the most critical parts of the cold chain and tends to be the weakest link. Data of foodborne diseases indicate that up to $87 \%$ of reported foodborne disease outbreaks occur at household level and improper handling, storage and preparation have a major role in this figure (Food Standards Agency, 2018; Redmond \& Griffith, 2003).

The current EU regulations establish that the responsibility of the safety of commercialized products relies on the FBO, who have to demonstrate to the competent authority that the food products they put on the market are safe throughout its shelf-life taking into account the reasonably foreseeable conditions of distribution, storage and use, thus including the normal storage and use by the consumers (European Commission, 2002, 2005). Reliable data on consumer storage conditions and up-to-date information on consumers' refrigerator temperatures is key for setting up shelf-life of perishable refrigerated products. This type of data was one of the identified data gaps that need to be fulfilled to reduce uncertainty of quantitative microbial risk assessments and to conclude on the quantitative impact of the factors contributing to food safety (EFSA BIOHAZ Panel, 2018; EURL Lm, 2014; Pérez-Rodríguez, Carrasco, Bover-Cid, Jofré, \& Valero, 2017). Moreover, data representativeness in relation to the temperature of the food products is in some cases limited as these characteristics depend on the type of measurement (discrete or continuous), its duration, the location of the probe (e.g. inside the refrigerator or on the surface or the inner parts of a product) and the sensitivity or thermal inertia of the probe.

Psychrotrophic bacteria that can grow during refrigerated storage are particularly of concern. This is the case of lactic acid bacteria (LAB) and Listeria monocytogenes in ready-to-eat (RTE) cooked meat products that have the potential to be contaminated with these microorganisms and support their growth to high numbers due to their physicochemical properties (EFSA BIOHAZ Panel, 2018). The contamination of cooked meat products commercialised in convenient formats (e.g. sliced and packaged under modified atmosphere or vacuum) with $L$. 
monocytogenes often occurs at the processing level as the pathogen may be present on equipment, facilities and at the point of sale, for example during slicing (EFSA, 2013). Though the initial levels due to exposure after post-lethality contamination are usually below the quantification limit (Jofré et al., 2016), the growth of the pathogen during storage of the product limits its shelf-life, known as the period during which the products keeps pathogen at levels below the maximun allowed level (i.e. $100 \mathrm{cfu} / \mathrm{g}$ in EU; European Comission, 2015). An extensive literature search reported prevalence of L. monocytogenes ranging between various studies from 0 to 50\% (mean 7\%) in cooked meats (Jofré et al, 2016). Additionally, cooked meat products are often highly perishable due to their $\mathrm{pH}$ and high water activity and when exposed to post-lethality contamination become high-risk foods regarding L. monocytogenes, particularly for elderly population and pregnant woman (EFSA-ECDC, 2018; Pérez-Rodríguez et al., 2017).

The aim of the present study was: $(i)$ to provide new data on general population (including the elderly) domestic refrigerators' time-temperature profiles representative of the temperature of refrigerated food, in particular RTE cooked meat products and (ii) to evaluate the effect of the storage temperature on the safety and the shelf-life of cooked meat products by simulating the growth of L. monocytogenes and LAB as the main pathogen and spoilage organisms, respectively.

\section{Material and Methods}

\subsection{Evaluation of thermal inertia of data loggers and cooked ham}

Temperature records of a 175-T1 data logger (Testo) were compared with the records of a 177T4 data logger (Testo) connected to T type thermocouple inserted in the centre of a 1-cm thick slice of cooked ham. The assembly was stabilized at $24^{\circ} \mathrm{C}$ in an incubator (Memmert IPP500, Schwabach, Germany) and subsequently put in a laboratory refrigerator (Heraeus Labor 140, Hanau, Germany) set at $5{ }^{\circ} \mathrm{C}$. After $16 \mathrm{~h}$, the assembly was put back to $24^{\circ} \mathrm{C}$. The study of the effect of door openings was performed by stabilizing at $5{ }^{\circ} \mathrm{C}$ an assembly consisting of a 175-T1 data logger, a thermocouple inserted in the centre of a 1-cm thick slice of cooked ham and a thermocouple measuring air temperature placed close to the same slice of cooked ham. The door of the refrigerator was opened four times (for 30, 30, 30 and $60 \mathrm{~s}$ ) every $5 \mathrm{~min}$. Each data logger recorded the temperature every $10 \mathrm{~s}$. Temperature values recorded by the data loggers were downloaded using Testo Comfort Basic software (Testo, Lenzkirch, Germany) and analysed with Microsoft Excel 2013 (Microsoft, Redmond, USA).

\subsection{Temperature data collection of domestic refrigerators}


The temperature of 160 domestic refrigerators of households was surveyed in Catalonia (Spain). Participants were selected to include small ( $<10,000$ habitants; $28 \%$ of households) and large population municipalities ( $>10,000$ habitants; $72 \%$ of households). Temperatures were monitored for a minimum period of $24 \mathrm{~h}$ with Testo 175-T1 data loggers (Testo, Alton, UK) programmed to record the temperature at $10 \mathrm{~min}$ intervals. Data loggers were calibrated within the range of temperatures recorded with a maximum permited error of $\pm 1^{\circ} \mathrm{C}$. Participants were asked to place data loggers in the position where they usually store cooked meat products and to fill in a brief questionnaire requesting information about: (i) Participant household basic information (age, gender and place of residence); (ii) Date and time of the beginning/end of the temperature recording; (iii) Brand of the refrigerator; (iv) Position of the data logger inside the refrigerator and (v) Refrigerator load level (i.e. nearly empty-half, full-completely, full). For a set of 20 refrigerators, the temperature was recorded twice, in the cold and the warm season. Recorded values were downloaded from the data loggers as described in section 2.1.

\subsection{Data analysis}

For each refrigerator, all temperatures recorded when the temperature of the data logger was stabilized were used to calculate the minimum, maximum, fluctuation amplitude, mean refrigerator temperature $\left(\overline{\mathrm{X}}_{24 \mathrm{~h}}\right)$, mean night temperature $\left(\overline{\mathrm{X}}_{\mathrm{Night}}\right.$, temperatures recorded from 21:00 to 08:59) and mean day temperature ( $\bar{X}_{\text {Day }}$, temperatures recorded from 9:00 to 20:59). The mean temperature of each refrigerator $\left(\bar{X}_{24 h}\right)$ was used to calculate the distribution of the $\overline{\mathrm{X}}_{24 \mathrm{~h}}$ in terms of mean, standard deviation, minimum, maximum, range, percentiles and percentage of domestic refrigerators showing $\bar{X}_{24 \mathrm{~h}}$ temperatures above $-2,-1,0,1,2,3,4,5,6$, $7,8,9,10,11,12{ }^{\circ} \mathrm{C}$. Cold and warm seasons were established based on the Catalonia monthly average air temperature (available at the Servei Meteorologic de Catalunya, www.meteo.cat) considering cold and warm season those months in which mean temperature was below $10^{\circ} \mathrm{C}$ or exceeded $20^{\circ} \mathrm{C}$, respectively. Elderly population households were considered those inhabited by people aged over $64(\mathrm{n}=27)$. Statistical analysis was conducted with T-test (for day-night and cold-warm season comparisons) and one-way ANOVA with the post-hoc Tukey test (for position and load level comparisons) using Statistica 8.0 software (Statsoft, Tulsa, UK).

\subsection{Simulation of growth of $\mathrm{L}$. monocytogenes and lactic acid bacteria in cooked meat products at different temperatures}

The growth behaviour of L. monocytogenes and LAB were estimated using the predictive model "Listeria monocytogenes in seafood and chilled meat products" and "Listeria monocytogenes and lactic acid bacteria" available at the Food Spoilage and Safety Predictor (FSSP v4.0, specific equations are shown in the help function of the application (http//fssp.food.dtu.dk/), 
which were satisfactorily validated for cooked meat products (Mejholm \& Dalgaard, 2009), demonstrating their reliability for predictive purposes. The following model inputs were used: (i) constant temperature and dynamic time-temperature profiles from surveyed domestic refrigerators were used as inputs of the predictive model; (ii) physico-chemical characteristics representative of cooked meat products currently available on the market: $\mathrm{pH}=6.0, \mathrm{a}_{\mathrm{w}}=0.974$, $\mathrm{NaCl}=2.9 \%$, residual nitrite below $5 \mathrm{mg} / \mathrm{kg}$, lactate $=0.75 \%$ and moisture $=73.63 \%$ (Bover-Cid, Jofré, Belletti, \& Garriga, 2015); (iii) no lag time was included in the simulation as a conservative (worst-case) scenario; (iv) L. monocytogenes initial contamination level was set at $1 \mathrm{cfu} / \mathrm{g}$, a conservative but reasonably foreseeable scenario (Ross, 2010) and several scenarios for $\mathrm{LAB}$ contamination, from 10 to $10^{5} \mathrm{cfu} / \mathrm{g}$ were assessed.

From the food safety perspective, the shelf-life of cooked meat products was established as the time required for L. monocytogenes to reach $100 \mathrm{cfu} / \mathrm{g}$, the maximum allowed level in several regulations (e.g. Regulation (EC) 2073/2005 (Europe), Policy on Listeria monocytogenes in Ready-to-Eat Foods (Canada), Food standards code 1.6.1 (Australia \& New Zealand)), i.e. time to 2-log increase (Hereu, Dalgaard, Garriga, Aymerich, \& Bover-Cid, 2014). Time to spoilage was estimated through the simulation of the growth of $\mathrm{LAB}$, which are known to be the main cause of spoilage of vacuum packaged cooked meat products when they reach $10^{7} \mathrm{cfu} / \mathrm{g}$ (EFSA BIOHAZ Panel, 2016). The effect of temperature and initial LAB counts to time to spoilage was investigated using the same physico-chemical characteristics described above as inputs of the predictive model.

\section{Results and discussion}

\subsection{Thermal inertia of the data loggers}

Figure 1A compares the temperature profiles registered by a Testo 175-T1 data logger and a highly responsive $\mathrm{T}$ type thermocouple inserted in the centre of a 1-cm thick slice of cooked ham. The profiles showed that both temperature decrease and increase was faster in the Testo 175-T1 data logger than in cooked ham when they were placed from room temperature to a refrigerator and vice versa. For example, it took 2.8 and $5.0 \mathrm{~h}$ to the data logger and the cooked ham, respectively, to decrease from $24^{\circ} \mathrm{C}$ to $5.5^{\circ} \mathrm{C}$. However, in the presence of frequent door openings once the assembly was stabilised in a laboratory refrigerator set at $5{ }^{\circ} \mathrm{C}$, the temperature profile of both the data logger and the cooked ham kept constant at 5.1-5.2 ${ }^{\circ} \mathrm{C}$, while the profile obtained with a thermocouple measuring air temperature fluctuated widely, with minimum and maximum temperatures of 3.3 and $8.7^{\circ} \mathrm{C}$, respectively (Figure 1B). In agreement, previous studies showed significantly lower temperature variations in foods or water than in the surrounding environment (Garrido, García-Jalón, \& Vitas, 2010; Raab et al., 2008). Conversely, in surveys using highly responsive probes, door openings were related to increased refrigerator temperature and mean and maximum temperature fluctuation ranges of $0.2-3.6{ }^{\circ} \mathrm{C}$ 
and 1.1-7.6 ${ }^{\circ} \mathrm{C}$, respectively, were recorded (Brennan, Kuznesof, Kendall, Olivier, \& Ladha, 2013). Accordingly, a temperature profile provided by the type of data logger used in the present study would be more representative from the temperature of food products stored in the refrigerator than a thermocouple measuring air temperature. Taking into account inertia studies, it would be expected that usual door openings in a household refrigerator would not produce wide fluctuations in the refrigerated products temperature nor have negative effects from the food safety point of view, despite it would increase the energy consumption of the refrigerator (Laguerre, Duret, Hoang, \& Flick, 2014; Saidur, Masjuki, Hasanuzzaman, \& Kai, 2008).

\subsection{Domestic refrigerators temperature analysis}

The analysis of the time-temperature profiles recorded from 160 domestic refrigerators belonging to 27 different brands showed, in general, a cyclical fluctuation of the temperature during the recorded period. The amplitude of the temperature fluctuation was highly variable, ranging from $0.5^{\circ} \mathrm{C}$ for the less fluctuating profile to $12.2^{\circ} \mathrm{C}$ for the most fluctuating profile, depending mainly on the refrigerator brand design and the on-off cycles of the compressor. No statistically significant differences between day and night were observed. Accordingly, differences in ambient temperature of the room (lower at night) or the frequency of door opening (higher during the day) did not cause relevant changes in the temperature profile recorded with the data logger and, according to the thermal inertia results, to the temperature of the food products stored in the refrigerators.

The mean $24 \mathrm{~h}$-temperature profiles $\left(\overline{\mathrm{X}}_{24 \mathrm{~h}}\right)$ of the surveyed refrigerators followed a normal distribution $\mathrm{N}($ mean $=5.4, \mathrm{SD}=2.3)$ with minimum and maximum $\overline{\mathrm{X}}_{24 \mathrm{~h}}$ values of -0.03 and 12.7 ${ }^{\circ} \mathrm{C}$, respectively (Figure $2 \mathrm{~A}$ ). A temperature of $5.4^{\circ} \mathrm{C}$ is within the range of temperatures appropriate for the preservation of perishable RTE meat products $\left(\leq 6^{\circ} \mathrm{C}\right)$, for which a strict control of the temperature and optimal values of $2-4^{\circ} \mathrm{C}$ are recommended (CAC, 2007).

However, $41 \%$ of the refrigerators showed $\overline{\mathrm{X}}_{24 \mathrm{~h}}$ temperatures above the recommended value of $6{ }^{\circ} \mathrm{C}$ (Figure $6 \mathrm{~B}$ ), the percentile $75^{\text {th }}$ being at $6.7^{\circ} \mathrm{C}$. These results are in agreement with the outputs of a recent review (James, Onarinde, \& James, 2017) showing that the use and temperature performance of household refrigerators has not remarkably changed over the last decades, showing mean air temperatures ranging from 3.5 to $9.3{ }^{\circ} \mathrm{C}$ in different countries. Despite the recommendations included in numerous food safety campaigns addressed to consumers, the storage of chilled foods is frequently performed at temperatures $>6{ }^{\circ} \mathrm{C}$, higher than those recommended by the Codex Alimentarius, Regulation (EC) 853/2004 and USA Food Code (CAC, 2007; European Commission, 2004; FDA, 2013).

\subsubsection{Effect of position and load level on refrigerator temperature}


Most of the interviewed consumers claimed to store cooked meat products in the refrigerator core (94\%), especially in the upper shelves. Only $4 \%$ stored them in the refrigerator door and $2 \%$ in specific extra-cold compartment (Table 1). The analysis of the temperatures registered in each position showed statistically different $\overline{\mathrm{X}}_{24 \mathrm{~h}}$ between the extra-cold compartment $\left(0.9^{\circ} \mathrm{C}\right.$, Standard Deviation $(\mathrm{SD})=0.6)$, the core of the refrigerator $\left(5.4^{\circ} \mathrm{C}, \mathrm{SD}=2.1\right)$ and the door $(8.0$ $\left.{ }^{\circ} \mathrm{C}, \mathrm{SD}=3.3\right)(\mathrm{p}<0.05)$. The position also affected the maximum and the minimum registered $\overline{\mathrm{X}}_{24 \mathrm{~h}}$ as well as the proportion of time at temperature $\geq 4{ }^{\circ} \mathrm{C}, \geq 6{ }^{\circ} \mathrm{C}$ and $\geq 8{ }^{\circ} \mathrm{C}(\mathrm{p}<0.05)$, but not the range of the $\overline{\mathrm{X}}_{24 \mathrm{~h}}$ (Table 1). Previous research showed no consistent results regarding the warmest and coldest temperature positions in a refrigerator and differences of more than $5{ }^{\circ} \mathrm{C}$ have been reported between different places in the same refrigerator being the door temperature always the warmest (Evans \& Redmond, 2016; Janjić et al., 2016; James et al., 2017; Marklinder \& Erikkson, 2015; Koutsoumanis, Pavlis, Nychas, \& Xanthiakos, 2010). However, when considering only those studies reporting simultaneous recordings of temperature in different positions of the refrigerator using a data logger (temperature measurement every 1 to $10 \mathrm{~min})$, the bottom shelves showed lower mean temperature values than top shelves $\left(0.7^{\circ} \mathrm{C}\right.$ lower in Marklinder \& Erikkson, 2015, $0.88^{\circ} \mathrm{C}$ lower in Koutsoumanis et al. (2010) and $0.34{ }^{\circ} \mathrm{C}$ lower in Janjić et al. (2016). In the present study, no significant differences were observed in the refrigerators mean $24 \mathrm{~h}$-temperature $\left(\overline{\mathrm{X}}_{24 \mathrm{~h}}\right)$ or range in relation with the refrigerator load level, which is in agreement with the findings showed by Evans and Redmond (Evans \& Redmond, 2016).

\subsubsection{Effect of season on refrigerators' temperature}

The analysis of the 24-h mean temperature values $\left(\overline{\mathrm{X}}_{24 \mathrm{~h}}\right)$ from warm and cold seasons did not show statistically significant differences $(\mathrm{p}>0.05)$ regarding the descriptors of the distribution of the $\overline{\mathrm{X}}_{24 \mathrm{~h}}$ values, i.e. mean, minimum, maximum, range or percentage of time during which $\overline{\mathrm{X}}_{24 \mathrm{~h}}$ refrigerator temperature was $\geq 4{ }^{\circ} \mathrm{C}$ and $\geq 8{ }^{\circ} \mathrm{C}$, though the values for warm season were slightly higher than those of the cold season (Figure 2C and 2D). To further assess the possible effect of ambient temperature on the storage temperature, 20 domestic refrigerators included in the survey were monitored both in cold and warm season. In this case, paired data comparison showed statistically significant $(\mathrm{p}<0.05)$ differences in the refrigerator temperature distribution depending on the season, with means of $4.7^{\circ} \mathrm{C}(\mathrm{SD}=2.0)$ in cold and $3.8^{\circ} \mathrm{C}(\mathrm{SD}=2.0)$ in warm season. Remarkably, $\overline{\mathrm{X}}_{24 \mathrm{~h}}$ mean and minimum temperatures were significantly lower $(\mathrm{p}<0.05)$ in warm season, with differences between seasons and for specific refrigerators, of up to $3.2^{\circ} \mathrm{C}$ in the mean and $5.2^{\circ} \mathrm{C}$ in the minimum temperature. These results could be explained, at least partially, by the fact that some of the consumers participating in the survey (i.e., 21.4\%) stated having set the thermostat to a lower temperature in the warm season. However, lower temperatures were also observed in refrigerators where no temperature modification was 
applied. In those cases, lower temperature levels should be explained by other reasons such as higher compressor on-off cycling in response to the higher ambient temperature. On the other side, the amplitude of the temperature fluctuations was lower in the cold season $(\mathrm{p}<0.05)$, probably due to the lower difference between ambient and refrigerator temperatures.

Previous surveys have evaluated domestic refrigerator temperatures. Two extensive reviews were published in 2008 and 2017 (James et al., 2017; James, Evans, \& James, 2008). The latter concluded that worldwide, the domestic storage of chilled food is highly variable and frequently performed at temperatures higher than those recommended for refrigerated storage and without improvement in the temperature performance in the last 30 years. The mean temperature determined in the present study, $5.4^{\circ} \mathrm{C}$, is in the range of those reported by previous studies, for instance $4.8^{\circ} \mathrm{C}(\mathrm{SD}=3.1)$ (Marklinder \& Erikkson, 2015); 5.2 ${ }^{\circ} \mathrm{C}(\mathrm{SD}=2.5)$ (Gilbert, Whyte, Bayne, Lake, \& van der Logt, 2007); $5.9^{\circ} \mathrm{C}(\mathrm{SD}=3.1)$ (Derens-Bertheau, Osswald, Laguerre, \& Alvarez, 2015) and slightly lower than $6.1^{\circ} \mathrm{C}$, the overall weighed arithmetic mean calculated by James et al. (2017) based on the results of 35 surveys worldwide. Taking into account the relevance of factors such as the type of measurement (discrete or continuous), the inertia of the device (data logger with a built-in sensor or connected to a highly sensitive probe), the matrix (air versus food product or water), the duration and frequency of the recording, the output data format (point estimate, mean or distribution), etc. on the reported mean temperature, the comparison of the results from different surveys, with temperature-measurement procedures not always well described, should be performed carefully. Additionally, when applying storage temperature data in microbial risk assessment and shelf-life studies, rather than data from sporadic point measurements, reliable temperature profile distributions such as those recorded in the present study are essential to draw consistent conclusions.

Refrigerator temperatures have a potential impact on the human listeriosis risk, an illness that has shown an increasing trend in the European Union and Economic Area during the last 9 years (EFSA-ECDC, 2018). Listeriosis cases are most frequently reported in the elderly population, a group more susceptible to this illness and for which unsafe practices such as storage time and temperature are quite common (> 10\% of persons studied) (EFSA BIOHAZ Panel, 2018). The findings of the present study confirm this fact as the percentage of time the $24 \mathrm{~h}$-mean temperature of the refrigerators is $\geq 8{ }^{\circ} \mathrm{C}$ was higher for the elderly $\left(22 \%, 75^{\text {th }}\right.$ percentile $\left.=7.3{ }^{\circ} \mathrm{C}\right)$ than for the general population $\left(8 \%, 75^{\text {th }}\right.$ percentile $\left.=6.6{ }^{\circ} \mathrm{C}\right)(\mathrm{p}<0.05)$.

\subsection{Refrigerator temperature impact on the shelf-life of RTE cooked meat products}

In shelf-life studies, the selection of the consumer storage temperature is critical because if the temperature is lower than the usually encountered there may be an underestimation of bacterial 
growth, and in case of L. monocytogenes an overestimation of the length of the shelf-life (EURL Lm, 2014). For this reason, the use of conditions of abuse of temperature such as the $75^{\text {th }}$ percentile of the observations made for the country have been recommended by several European guidelines (e.g. EURL Lm, 2014; Food Safety Authority of Ireland, 2017) or $12^{\circ} \mathrm{C}$ if consumer storage temperature information is not available (EURL Lm, 2014). Roccato, Uyttendaele, \& Membré (2017), after the analysis of temperature distributions of European domestic refrigerators from literature, determined that the overall temperature variability for the southern and northern Europe countries was described by the normal distributions $\mathrm{N}(7.0,2.7)$ ${ }^{\circ} \mathrm{C}$ and $\mathrm{N}(6.1,2.8){ }^{\circ} \mathrm{C}$, respectively. Based on these distributions, they recommend 8.0 and 8.5 ${ }^{\circ} \mathrm{C}$ as $75^{\text {th }}$ percentile temperatures for northern and southern EU countries, respectively. More specifically, a temperature of $8{ }^{\circ} \mathrm{C}$ is recommended for the consumer storage phase of shelf-life studies performed in Ireland (Food Safety Authority of Ireland, 2017), while slightly lower temperature, i.e. $7^{\circ} \mathrm{C}$, is recommended by other guidelines to account for expected consumer storage temperature (Betts, 2010; NACMCF, 2010). The results of the present study provide the scientific documentation that the FBO can use to justify conducting shelf-life studies at $6.7^{\circ} \mathrm{C}$, as the $75^{\text {th }}$ percentile temperature of the Spanish consumer storage stage.

The use of predictive microbiology has become an important and recognized tool for assessing and managing food safety, particularly regarding shelf-life studies for RTE products (EURL Lm, 2014; European Commission, 2005, 2013; Messens, Hempen, \& Koutsoumanis, 2018). In the present study predictive models have been used to evaluate the impact of the refrigerator temperatures on the growth of L. monocytogenes (indicating shelf-life limit as time to 2-log increase) and LAB causing spoilage (when reaching $10^{7} \mathrm{cfu} / \mathrm{g}$ ) in a standard cooked meat product (see section 2.4). Table 2 shows the results of the simulations carried out. Regarding the L. monocytogenes growth, at the mean temperature recorded for domestic refrigerators, $5.4^{\circ} \mathrm{C}$, the shelf-life for a typical cooked meat product would be around 12 days. At a reference refrigeration temperature of $4{ }^{\circ} \mathrm{C}$ the predicted shelf-life for the same cooked meat product would be of at least 3 weeks, while at $10{ }^{\circ} \mathrm{C}$ it would be reduced to 4.2 days, corresponding to a shelf-life 5 and 20 -fold lower than the estimated at 4 and $2{ }^{\circ} \mathrm{C}$, respectively.

Regarding the growth of $\mathrm{LAB}$, the simulations indicate that the time to reach the spoilage level is generally shorter than the time taken by L. monocytogenes to increase $2 \log$ units, particularly when the storage temperature is below $5{ }^{\circ} \mathrm{C}$ and/or the initial $\mathrm{LAB}$ contamination is relatively high. In these scenarios, the ratio between the time to 2-log increase of the pathogen (i.e. safe time) and the time to spoilage is higher than 1, thus the product would be spoiled before the pathogen reaches the safety level permitted by the current EU legislation. It is worth to highlight that for products with low initial contamination by LAB (e.g. sliced under aseptic conditions in a clean room) stored at temperatures equal or higher than $5{ }^{\circ} \mathrm{C}$ (e.g. which correspond to $c a$. 
$50 \%$ of the mean temperature recorded for domestic refrigerators in the present study), the ratio between the safe and spoilage time is lower than 1. These scenarios constitute risk areas as defined by Devlieghere et al. (2001) in which food pathogens can develop before spoilage has occurred.

As shown in the present study, the fluctuation of the temperature observed in refrigerators can be, in some cases, remarkable and refrigerator temperature profiles with the same mean temperature can have very different amplitude, a fact that can be relevant from the food safety point of view. Figure 3 shows some examples of profiles showing the same mean temperature but different fluctuation pattern. At $6.8^{\circ} \mathrm{C}$, the highest mean temperature depicted in Fig 3 (A), the time to 2-log increase of L. monocytogenes in cooked ham was the shortest (7.5 days) and no remarkable differences were observed between the two different patterns of fluctuation and the constant temperature. At a mean temperature of $3.9^{\circ} \mathrm{C}$ (Fig 3B) a slight decrease in the time to 2-log increase was observed when temperature fluctuated more (profile B1), with a relative shelf-life when compared with storage at constant temperature of $87 \%$. The highest reduction of the shelf-life was observed at the lower mean temperature evaluated $\left(2.1^{\circ} \mathrm{C}, \mathrm{Fig} 3 \mathrm{C}\right)$. When compared to a $2.1{ }^{\circ} \mathrm{C}$ constant temperature, profile $\mathrm{C} 1\left(6.2^{\circ} \mathrm{C}\right.$ of amplitude) and profile $\mathrm{C} 2(2.2$ ${ }^{\circ} \mathrm{C}$ of amplitude) showed relative shelf-life of 62 and 93\%, respectively. Taken together, figures show that the effect of temperature fluctuation is higher at low temperatures and, in general, the higher the amplitude of the fluctuation the higher the shelf-life reduction as the growth rate of $L$. monocytogenes increases exponentially with temperature (Hereu et al., 2014; Mejlholm \& Dalgaard, 2009). Consequently, to evaluate the effect of temperature on the shelf-life of RTE food under reasonably foreseeable conditions of storage, not only the mean of the temperature distribution but also the magnitude of the fluctuation (variability) should be considered. In contrast, amplitude of the temperature fluctuation had a lower impact on the time taken by LAB to reach the spoilage level (Table 3) in comparison with the effect on the time to 2-log increase of the pathogen. These results can be explained by the different effect of storage temperature changes on each parameter. As shown in Table 2, the rise of temperature from $2{ }^{\circ} \mathrm{C}$ to $4{ }^{\circ} \mathrm{C}$ reduced the time to $2-\log$ increase of L. monocytogenes by $75 \%$, while the same temperature increase caused a 39\% reduction of the time to reach the spoilage level by LAB. The impact of the amplitude of temperature fluctuation on the ratio between the shelf-life determined by the growth of the pathogen and that limited by the growth of spoilage LAB was very limited. In agreement with the results of the simulation at constant temperature, the scenarios at risk were detected for the temperature profiles with mean values of $6.8^{\circ} \mathrm{C}(\mathrm{A} 1, \mathrm{~A} 2$ and A3) when the initial LAB were low (Table 3). 
Considering that a remarkable proportion of domestic refrigerators operate at mean temperatures outside the range recommended for perishable products and the high impact that temperature has on the growth of L. monocytogenes in cooked meat products in particular and the food safety of RTE food in general, the increase of consumers' awareness in relation to refrigeration practices would be an effective measure to promote food safety and reduce food waste.

Declaration of Competing Interest Authors have no conflict of interests.

\section{Acknowledgements}

This work was supported by the Instituto Nacional de Investigación y Tecnología Agraria y Alimentaria INIA-RTA2011-00030 project (Ministerio de Economía, Industria y Competitividad, Spain) and by the CERCA Programme/Generalitat de Catalunya.

\section{References}

Betts, G. (2010). Challenge testing protocols for assessing the safety and quality of food and drink. Campden BRI Guideline $n^{\circ} 63$.

Bover-Cid, S., Jofré, A., Belletti, N., \& Garriga, M. (2015). Quantitative data collection about physico-chemical characteristics of RTE cooked meat products for Listeria monocytogenes exposure assessment. In 2nd EFSA Scientific Conference "Shaping the Future of Food Safety, Together". Milan (Italy): EFSA Journal 13(10):s1310.

Brennan, M., Kuznesof, S., Kendall, H., Olivier, P., \& Ladha, C. (2013). Activity Recognition and Temperature Monitoring (ART) Feasibility Study. Unit 25 report, Social Science Research Unit, Food Standards Agency. London, UK.

CAC. (2007). Guidelines on the application of general principles of food hygiene to the control of Listeria monocytogenes in foods. CAC/GL 61-2007. In Codex Alimentarius (pp. 1-28).

Derens-Bertheau, E., Osswald, O., Laguerre, O., \& Alvarez, G. (2015). Cold chain of chilled food in France. International Journal of Refrigeration, 52, 161-167.

Devlieghere, F., Geeraerd, A. H., Versyck, K. J., Vandewaetere, B., Van Impe, J., \& Debevere, J. (2001). Growth of Listeria monocytogenes in modified atmosphere packed cooked meat products: a predictive model. Food Microbiology, 18 (1), 53-66. 
EFSA-ECDC. (2018). The European Union summary report on trends and sources of zoonoses, zoonotic agents and food-borne outbreaks in 2017. EFSA Journal, 16 (12), 262.

EFSA. (2008). Request for updating the former SCVPH opinion on Listeria monocytogenes risk related to ready-to-eat foods and scientific advice on different levels of Listeria monocytogenes in ready-to-eat foods and the related risk for human illness. EFSA Journal, 6 (1), 599-641.

EFSA. (2013). Analysis of the baseline survey on the prevalence of Listeria monocytogenes in certain ready-to-eat foods in the EU, 2010-2011 Part A: Listeria monocytogenes prevalence estimates. The EFSA journal, 11 (6), 1-75.

EFSA BIOHAZ Panel. (2016). Growth of spoilage bacteria during storage and transport of meat. EFSA Journal, 14 (6), 4523.

EFSA BIOHAZ Panel. (2018). Listeria monocytogenes contamination of ready-to-eat foods and the risk for human health in the EU. EFSA Journal, 16 (1), 5134.

EURL Lm. (2014). Technical guidance document for conducting shelf-life studies on Listeria monocytogenes in ready-to-eat foods. Version 3 - 06/06/2014. MaisonsAlfort, France: EURL Listeria monocytogenes, ANSES. Available at https://ec.europa.eu/food/sites/food/files/safety/docs/biosafety_fh_mc_technical _guidance_document_listeria_in_rte_foods.pdf Accessed 30 January 2019.

European Commission. (2002). Regulation (EC) N 178/2002 of the European Parliament and of the Council of 28 January 2002 laying down the general principles and requirements of food law, establishing the European Food Safety Authority and laying down procedures in matters of food safety. In Official Journal L31/1.

European Commission. (2004). Regulation (EC) No853/2004 of the European Parliament and of the Council of 29 April 2004 laying down specific hygiene rules for food of animal origin. In Official Journal of the European CommunitiesL 139/55.

European Commission. (2005). Regulation (EC) No 2073/2005 of 15 November 2005 on microbiological criteria for foodstuffs. In Official Journal of the European Union L 338/1.

European Commission. (2013). Guidance Document on Listeria monocytogenes shelflife studies for ready-to-eat foods under Regulation (EC) No 2073/2005 of 15 November 2005 on microbiological criteria for foodstuffs. Available at 
https://ec.europa.eu/food/sites/food/files/safety/docs/biosafety_fh_mc_guidance _document_lysteria.pdf Accessed 30 January 2019.

Evans, E. W., \& Redmond, E. C. (2016). Time-temperature profiling of United

Kingdom consumers'domestic refrigerators. Journal of Food Protection, 79 (12), 2119-2127.

FDA. (2013). Food Code 2013. In F. a. D. A. U. S. Public Health Service (Ed.). College Park, MD 20740, USA.

Food Safety Authority of Ireland. (2017). Guidance Note No. 18: Determination of Product Shelf-Life (Revision 3). Available at https://www.fsai.ie/faq/shelf_life/determination.html Accessed 30 January 2019.

Food Standards Agency. (2018). Systematic review of the relative proportion of foodborne disease associated with food preparation or handling practices in the home. Final report. Reference FS101098. Available at https://www.food.gov.uk/sites/default/files/media/document/fs101098fbdintheho metechnicalrep.pdf Accessed 30 January 2019.

Garrido, V., García-Jalón, I., \& Vitas, A. I. (2010). Temperature distribution in Spanish domestic refrigerators and its effect on Listeria monocytogenes growth in sliced ready-to-eat ham. Food Control, 21 (6), 896-901.

Gilbert, S. E., Whyte, R., Bayne, G., Lake, R. J., \& van der Logt, P. (2007). Survey of internal temperatures of New Zealand domestic refrigerators. British Food Journal, 109 (4), 323-329.

Hereu, A., Dalgaard, P., Garriga, M., Aymerich, T., \& Bover-Cid, S. (2014). Analysing and modelling the growth behaviour of Listeria monocytogenes on RTE cooked meat products after a high pressure treatment at $400 \mathrm{MPa}$. International Journal of Food Microbiology, 186, 84-94.

James, C., Onarinde, B. A., \& James, S. J. (2017). The use and performance of household refrigerators: A review. Comprehensive Reviews in Food Science and Food Safety, 16 (1), 160-179.

James, S. J., Evans, J., \& James, C. (2008). A review of the performance of domestic refrigerators. Journal of Food Engineering, 87 (1), 2-10.

Janjić, J., Katić, V., Ivanović, J., Bošković, M., Starčević, M., Glamočlija, N., \& Baltić, M. Ž. (2016). Temperatures, cleanliness and food storage practises in domestic refrigerators in Serbia, Belgrade. International Journal of Consumer Studies, 40 (3), 276-282. 
Jofré, A., Garriga, M., Aymerich, T., Pérez-Rodríguez, F., Valero, A., Carrasco, E., \& Bover-Cid, S. (2016). Closing gaps for performing a risk assessment on Listeria monocytogenes in ready-to-eat (RTE) foods: Activity 1, an extensive literature search and study selection with data extraction on L. monocytogenes in a wide range of RTE food. EFSA Supporting Publications, 13 (12), 1141E.

Koutsoumanis, K., Pavlis, A., Nychas, G.-J. E., \& Xanthiakos, K. (2010). Probabilistic model for Listeria monocytogenes growth during distribution, retail storage, and domestic storage of pasteurized milk. Applied and Environmental Microbiology, 76 (7), 2181-2191.

Laguerre, O., Duret, S., Hoang, H. M., \& Flick, D. (2014). Using simplified models of cold chain equipment to assess the influence of operating conditions and equipment design on cold chain performance. International Journal of Refrigeration, 47, 120-133.

Marklinder, I., \& Erikkson, M. K. (2015). Best-before date - food storage temperatures recorded by Swedish students. British Food Journal, 117 (6), 1764-1776.

Mejlholm, O., \& Dalgaard, P. (2009). Development and validation of an extensive growth and growth boundary model for Listeria monocytogenes in lightly preserved and ready-to-eat shrimp. Journal of Food Protection, 72 (10), 21322142 .

Messens, W., Hempen, M., \& Koutsoumanis, K. (2018). Use of predictive modelling in recent work of the Panel on Biological Hazards of the European Food Safety Authority. Microbial Risk Analysis, 10,37-43.

NACMCF. (2010). Parameters for determining inoculated pack/challenge study protocols. Journal of Food Protection, 73 (1), 140-202.

Pérez-Rodríguez, F., Carrasco, E., Bover-Cid, S., Jofré, A., \& Valero, A. (2017). Closing gaps for performing a risk assessment on Listeria monocytogenes in ready-to-eat (RTE) foods: Activity 2, a quantitative risk characterization on $L$. monocytogenes in RTE foods; starting from the retail stage. EFSA Supporting Publications, 14 (7), EN-1252E.

Raab, V., Bruckner, S., Beierle, E., Kampmann, Y., Petersen, B., \& Kreyenschmidt, J. (2008). Generic model for the prediction of remaining shelf life in support of cold chain management in pork and poultry supply chains. Journal on Chain and Network Science, 8, 59-73. 
Redmond, E. C., \& Griffith, C. J. (2003). Consumer food handling in the home: A review of food safety studies. Journal of Food Protection, 66 (1), 130-161.

Roccato, A., Uyttendaele, M., \& Membré, J.-M. (2017). Analysis of domestic refrigerator temperatures and home storage time distributions for shelf-life studies and food safety risk assessment. Food Research International, 96 (Supplement C), 171-181.

Ross, T. (2010). Defining "short shelf life" foods with respect to risk from Listeria monocytogenes. In (pp. 31): University of Tasmania.

Saidur, R., Masjuki, H. H., Hasanuzzaman, M., \& Kai, G. S. (2008). Investigation of energy performance and usage behavior of domestic refrigerator freezer using clustering and segmentation. Journal of Applied Sciences, 8 (21), 3957-3962.

Figure 1. Temperature profiles from an assembly consisting of a 175-T1 Testo data logger and a $\mathrm{T}$ type thermocouple measuring the core temperature of a 1-cm thick slice of cooked ham. A: Assembly was stabilized at $24^{\circ} \mathrm{C}$, transferred to a $5{ }^{\circ} \mathrm{C}$-refrigerator for $16 \mathrm{~h}$ and transferred back to $24{ }^{\circ} \mathrm{C}$ for $5 \mathrm{~h}$. B: Assembly was stabilized at a $5{ }^{\circ} \mathrm{C}$-refrigerator and submitted to door openings (arrows) every 5 min.

Figure 2. Distribution of the mean 24h-temperature profile $\left(\overline{\mathrm{X}}_{24 \mathrm{~h}}\right)$ of the 160 surveyed domestic refrigerators (A) and refrigerators surveyed in cold (C) and warm (D) season. Percentage of refrigerators (B) with mean temperatures at optimum $\left(<4{ }^{\circ} \mathrm{C}\right)$, acceptable $\left(4-6{ }^{\circ} \mathrm{C}\right)$ and abuse temperatures $\left(>6^{\circ} \mathrm{C}\right.$ ). Mean, minimum (Min), maximum (Max) and range of $\overline{\mathrm{X}}_{24 \mathrm{~h}}$ are indicated for each plot.

Figure 3. Temperature profiles of domestic refrigerators with mean temperature of $6.8^{\circ} \mathrm{C}(\mathrm{A})$, $3.9^{\circ} \mathrm{C}(\mathrm{B})$ and $2.1{ }^{\circ} \mathrm{C}(\mathrm{C})$. For each mean temperature, profiles of two different refrigerators are shown (1 and 2) in comparison with the constant temperature (3) at the mean value. Relative shelf-life percentage (RSL) was calculated in relation to the maximum shelf-life at the selected constant temperature profile. Shelf-life indicated as the time to 2-log increase of L. monocytogenes levels.

Table 1. Reported positions of storage of cooked meat products in domestic refrigerators . Statistical descriptive parameters calculated from the mean 24h-temperature profiles $\left(\overline{\mathrm{X}}_{24 \mathrm{~h}}\right)$ registered for each refrigerator at the monitored position.

\begin{tabular}{|c|c|c|c|c|c|c|c|c|c|}
\hline \multirow{2}{*}{ Position } & \multirow{2}{*}{$\begin{array}{l}\text { Frequency } \\
(\%) \text { of } \\
\text { refrige rators }\end{array}$} & \multicolumn{4}{|c|}{ Tempe rature $\left({ }^{\circ} \mathrm{C}\right)$} & \multicolumn{4}{|c|}{ Percentage of time at: } \\
\hline & & Mean & Min & Max & Range & $\begin{array}{l}<4 \\
{ }^{\circ} \mathrm{C}\end{array}$ & $\begin{array}{l}\geq 4 \\
\geq{ }^{\circ} \mathrm{C}\end{array}$ & $\begin{array}{r}\geq 6 \\
{ }^{\circ} \mathbf{C}\end{array}$ & $\begin{array}{r}\geq 8 \\
{ }^{\circ} \mathbf{C}\end{array}$ \\
\hline
\end{tabular}




\begin{tabular}{|c|c|c|c|c|c|c|c|c|c|c|}
\hline Core & & 94 & $5.4^{\mathrm{a}}$ & $3.9^{\mathrm{a}}$ & $7.4^{\mathrm{a}}$ & $3.5^{\mathrm{a}}$ & $25.5^{\mathrm{a}}$ & $74.5^{\mathrm{a}}$ & $41.7^{\mathrm{a}}$ & $12.3^{\mathrm{a}}$ \\
\hline $\begin{array}{l}\text { Upper } \\
\text { shelves }\end{array}$ & 59 & & $5.8^{\mathrm{A}}$ & $4.1^{\mathrm{A}}$ & $6.8^{\mathrm{A}}$ & $3.8^{\mathrm{A}}$ & $18.6^{\mathrm{A}}$ & $81.4^{\mathrm{A}}$ & $48.7^{\mathrm{A}}$ & $14.8^{\mathrm{A}}$ \\
\hline $\begin{array}{l}\text { Lower } \\
\text { shelves }\end{array}$ & 41 & & $5.0^{\mathrm{B}}$ & $3.6^{\mathrm{A}}$ & $7.9^{\mathrm{B}}$ & $3.2^{\mathrm{A}}$ & $34.6^{\mathrm{B}}$ & $65.4^{\mathrm{B}}$ & $33.0^{\mathrm{B}}$ & $10.4^{\mathrm{A}}$ \\
\hline Door & & 4 & $8.0^{\mathrm{b}}$ & $5.8^{\mathrm{a}}$ & $10.4^{\mathrm{b}}$ & $4.6^{\mathrm{a}}$ & $11.6^{\mathrm{a}}$ & $88.4^{\mathrm{a}}$ & $72.8^{\mathrm{b}}$ & $48.1^{b}$ \\
\hline $\begin{array}{l}\text { Extra cold } \\
\text { compartment }\end{array}$ & & 2 & $0.9^{c}$ & $0.1^{\mathrm{b}}$ & $2.2^{\mathrm{c}}$ & $2.4^{\mathrm{a}}$ & $100^{\mathrm{b}}$ & $0^{\mathrm{b}}$ & $0^{c}$ & $0^{c}$ \\
\hline $\begin{array}{l}\text { Overall } \\
\text { values }^{\mathrm{a}}\end{array}$ & & 100 & 5.4 & 0.0 & 12.2 & 3.7 & 28.7 & 71.3 & 41.3 & 10.6 \\
\hline
\end{tabular}

Values with different superscript small letters indicate statistically significant differences between different positions and different superscript capital letters indicate statistically significant differences between upper and lower shelves $(\mathrm{p}<0.05)$.

${ }^{a}$ The same as shown in Figure 2A

Table 2. Results of the estimated shelf-life (time to 2-log increase of L. monocytogenes and time to spoilage) of RTE cooked ham stored at different temperatures according to the simulation ${ }^{1}$ of the growth of L. monocytogenes and LAB, respectively. The ratio between both times is shown in parenthesis.

\begin{tabular}{|c|c|c|c|c|c|c|c|}
\hline \multirow[t]{2}{*}{$\begin{array}{l}\text { Temper } \\
\text { ature }\end{array}$} & \multirow[t]{2}{*}{$\begin{array}{l}\text { Time (days) to } 2 \text {-log increase } \\
\text { of } L \text {. monocytogenes }\end{array}$} & \multicolumn{6}{|c|}{$\begin{array}{l}\text { Time (days) to reach spoilage le vel } \\
\text { from diffe re nt initial conce ntrations }\left(\mathrm{N}_{0}\right) \text { of } \\
\text { LAB }\end{array}$} \\
\hline & & $\begin{array}{l}\mathrm{N}_{0}=10 \\
\text { cfu/g }\end{array}$ & $\begin{array}{l}\mathrm{N}_{0}=10^{2} \\
\text { cfu/g }\end{array}$ & $\begin{array}{l}\mathrm{N}_{0}=10^{3} \\
\text { cfu/g }\end{array}$ & $\begin{array}{l}\mathrm{N}_{0}=10^{4} \\
\text { cfu/g }\end{array}$ & & \\
\hline $2^{\circ} \mathrm{C}$ & 90.0 & $\begin{array}{ll}27 . & (3 . \\
1 & 3)\end{array}$ & $\begin{array}{ll}22 . & (4 . \\
6 & 0)\end{array}$ & $\begin{array}{ll}18 . & (5 . \\
1 & 0)\end{array}$ & $\begin{array}{ll}13 . & (6 . \\
6 & 6)\end{array}$ & 9.1 & $\begin{array}{l}\text { (9. } \\
9)\end{array}$ \\
\hline $4^{\circ} \mathrm{C}$ & 22.6 & $\begin{array}{ll}16 . & (1 . \\
6 & 4)\end{array}$ & $\begin{array}{ll}13 . & (1 . \\
9 & 6)\end{array}$ & $\begin{array}{ll}11 . & (2 . \\
1 & 0)\end{array}$ & $\begin{array}{cc}8.3 \quad(2 . \\
& 7)\end{array}$ & 5.6 & $\begin{array}{l}\text { (4. } \\
1)\end{array}$ \\
\hline $5^{\circ} \mathrm{C}$ & 14.1 & $\begin{array}{ll}\text { 13. } & (1 . \\
5 & 0)^{2}\end{array}$ & $\begin{array}{ll}11 . & (1 . \\
3 & 2)\end{array}$ & $\begin{array}{cc}9.0 \quad(1 . \\
& 6)\end{array}$ & $\begin{array}{cc}6.8 \quad(2 . \\
& 1)\end{array}$ & 4.5 & $\begin{array}{l}(3 . \\
1)\end{array}$ \\
\hline $6^{\circ} \mathrm{C}$ & & $\begin{array}{ll}\text { 11. } & (0 . \\
2 & 9)\end{array}$ & $\begin{array}{cc}9.4 \quad(1 . \\
& 0)\end{array}$ & $\begin{array}{ll}7.5 \quad(1 . \\
& 3)\end{array}$ & $\begin{array}{ll}5.6 \quad(1 . \\
& 7)\end{array}$ & 3.8 & $\begin{array}{l}(2 . \\
6)\end{array}$ \\
\hline $10^{\circ} \mathrm{C}$ & 4.2 & $\begin{array}{cc}6.1 & (0 . \\
& 7)\end{array}$ & $\begin{array}{ll}5.1 & (0 . \\
& 8)\end{array}$ & $\begin{array}{cc}4.1 & (1 . \\
& 0)\end{array}$ & $\begin{array}{ll}3.1 \quad(1 . \\
& 4)\end{array}$ & 2.1 & $\begin{array}{l}(2 . \\
1)\end{array}$ \\
\hline
\end{tabular}

${ }^{1}$ Simulations were carried out with the predictive models available on the FSSP v4.0 using input values representative of RTE cooked meat products as described in section 2.4.

${ }^{2}$ Scenarios at risk, i.e. the ratio between the time to 2-log increase of the pathogen and the time to spoilage is equal or lower than 1 , are highlighted in bold. 
Table 3. Results of the estimated shelf-life (time to 2-log increase of L. monocytogenes and time to spoilage) of RTE cooked ham stored at different temperature profiles ${ }^{\text {a }}$ showing the same mean temperature according to the simulation ${ }^{\mathrm{b}}$ of the growth of $L$. monocytogenes and $\mathrm{LAB}$, respectively. The ratio between both times is shown in parenthesis.

\begin{tabular}{|c|c|c|c|c|c|c|c|c|c|c|c|}
\hline \multirow{2}{*}{$\begin{array}{l}\text { Mean } \\
\text { tempe } \\
\text { rature }\end{array}$} & \multirow{2}{*}{$\begin{array}{l}\text { Pr } \\
\text { ofil } \\
\text { e }\end{array}$} & \multirow{2}{*}{$\begin{array}{l}\text { Time } \\
\text { (days) to 2-log increase } \\
\text { of } L \text {. monocytogenes }\end{array}$} & \multicolumn{9}{|c|}{$\begin{array}{l}\text { Time (days) to reach spoilage le vel from diffe rent } \\
\text { initial concentrations }\left(N_{0}\right) \text { of } L A B\end{array}$} \\
\hline & & & $\begin{array}{l}\mathrm{N}_{0}=10 \\
\text { cfu/g }\end{array}$ & $\begin{array}{l}\mathrm{N}_{0}=1 \\
\mathrm{cfu} / \mathrm{g}\end{array}$ & & $\begin{array}{l}\mathrm{N}_{0}= \\
\text { cfu }\end{array}$ & $\begin{array}{l}10^{3} \\
\mathrm{~g}\end{array}$ & $\begin{array}{l}\mathbf{N}_{0} \\
\text { cfu }\end{array}$ & $\begin{array}{l}10^{4} \\
\mathrm{~g}\end{array}$ & $\begin{array}{l}\mathrm{N}_{0}=1 \\
\mathrm{cfu} / \mathrm{g}\end{array}$ & \\
\hline \multirow[t]{6}{*}{$2.1^{\circ} \mathrm{C}$} & $\mathrm{C} 1$ & 51.6 & $24 . \quad(2.1$ & 20. & $(2.5$ & 16. & $(3.1$ & 12 . & $(4.2$ & 8.3 & (6.2 \\
\hline & & & $7)$ & 6 & ) & 4 & 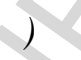 & 3 & ) & & ) \\
\hline & $\mathrm{C} 2$ & 78.1 & 25. & 21. & (3.5 & 17. & (4.4 & 12 . & $(5.9$ & 8.7 & (8.8 \\
\hline & & & $7)$ & 5 & ) & 2 & ) & 9 & ) & & ) \\
\hline & $\mathrm{C} 3$ & 84.3 & 26. $\quad(3.2$ & 22. & (3.8 & 17. & $(4.8$ & 13. & $(6.4$ & 8.8 & $(9.5$ \\
\hline & & & 3 & 0 & $f$ & 6 & ) & 2 & ) & & ) \\
\hline \multirow[t]{6}{*}{$3.9^{\circ} \mathrm{C}$} & B1 & 19.9 & $16 . \quad(1.2$ & 13. & $(1.5$ & 11. & $(1.8$ & 8.2 & $(2.4$ & 5.5 & (3.6 \\
\hline & & & 4 & 7 & ) & 0 & ) & & ) & & ) \\
\hline & B2 & 22.9 & $(1.4$ & 14. & (1.6 & 11. & $(2.0$ & 8.4 & $(2.7$ & 5.7 & $(4.0$ \\
\hline & & & 9 & 1 & ) & 3 & ) & & ) & & ) \\
\hline & B3 & 23.3 & 17. (1.4 & 14. & $(1.7$ & 11. & $(2.0$ & 8.5 & $(2.7$ & 5.8 & $(4.0$ \\
\hline & & & ) & 1 & ) & 4 & ) & & ) & & ) \\
\hline \multirow[t]{6}{*}{$6.8^{\circ} \mathrm{C}$} & A1 & 7.7 & $\begin{array}{ll}9.8 & (0.8\end{array}$ & 8.2 & $(0.9$ & 6.6 & $(1.2$ & 4.9 & $(1.6$ & 3.3 & $(2.4$ \\
\hline & & & )$^{c}$ & & ) & & ) & & ) & & ) \\
\hline & $\mathrm{A} 2$ & 7.5 & $9.8 \quad(0.8$ & 8.1 & $(0.9$ & 6.5 & $(1.1$ & 4.9 & $(1.5$ & 3.3 & $(2.3$ \\
\hline & & & ) & & ) & & ) & & ) & & ) \\
\hline & $\mathrm{A} 3$ & 7.5 & $9.8 \quad(0.8$ & 8.2 & $(0.9$ & 6.5 & $(1.1$ & 4.9 & $(1.5$ & 3.3 & $(2.3$ \\
\hline & & & ) & & ) & & ) & & ) & & ) \\
\hline
\end{tabular}

${ }^{\text {a Temperature profiles shown in Table } 3 .}$

${ }^{\mathrm{b}}$ Simulations were carried out with the predictive models available on the FSSP v4.0 using input values representative of RTE cooked meat products as described in section 2.4.

${ }^{\mathrm{c}}$ Scenarios at risk, i.e. the ratio between the time to 2-log increase of the pathogen and the time to spoilage ratio is equal or lower than 1 , are highlighted in bold.

\section{Graphical abstract}

\section{Highlights}

- The mean $24 \mathrm{~h}$-temperature of 160 surveyed domestic refrigerators was $5.4^{\circ} \mathrm{C}$

- The study indicates $6.7^{\circ} \mathrm{C}$ as the $75^{\text {th }}$ percentile for consumer storage stage 
- Risk scenarios where L. monocytogenes develops before LAB spoilage were identified

- Temperature fluctuation negatively affects the safety of RTE products 

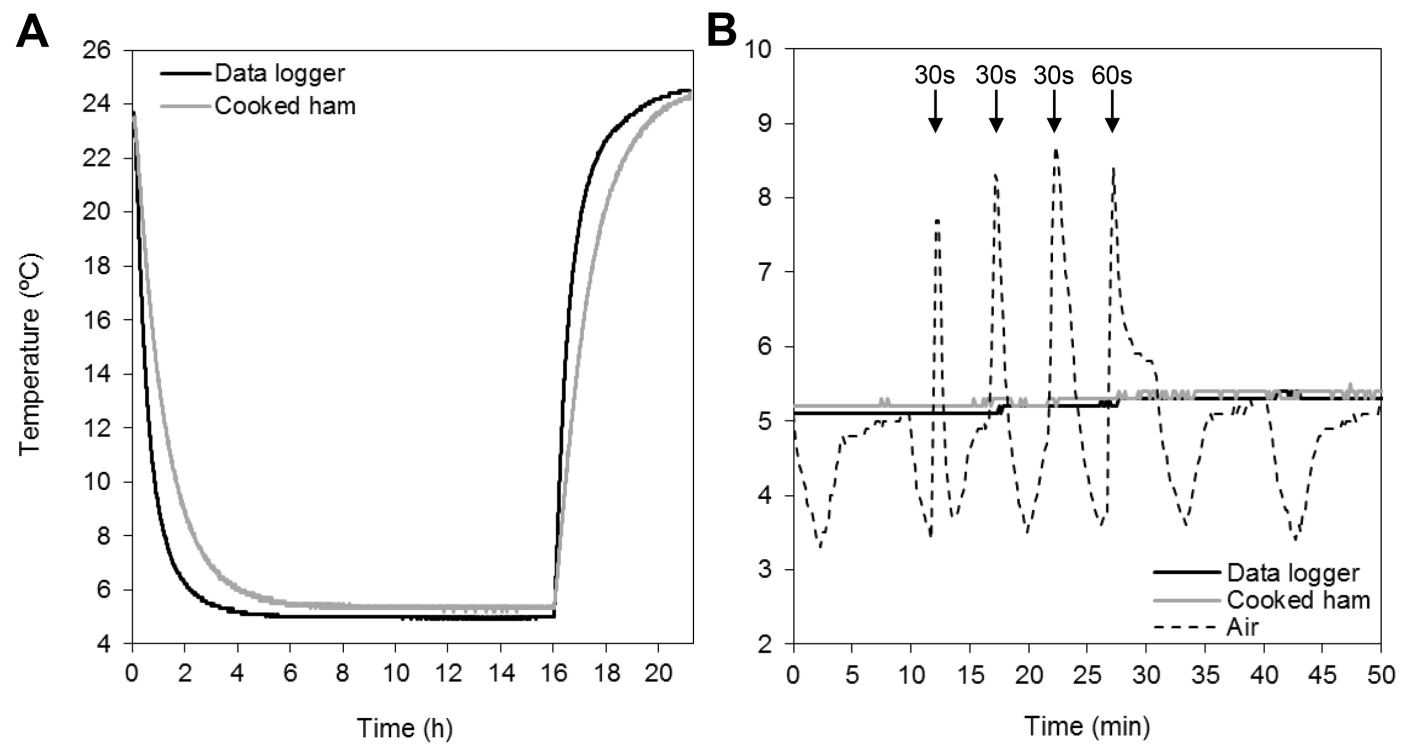

Figure 1 

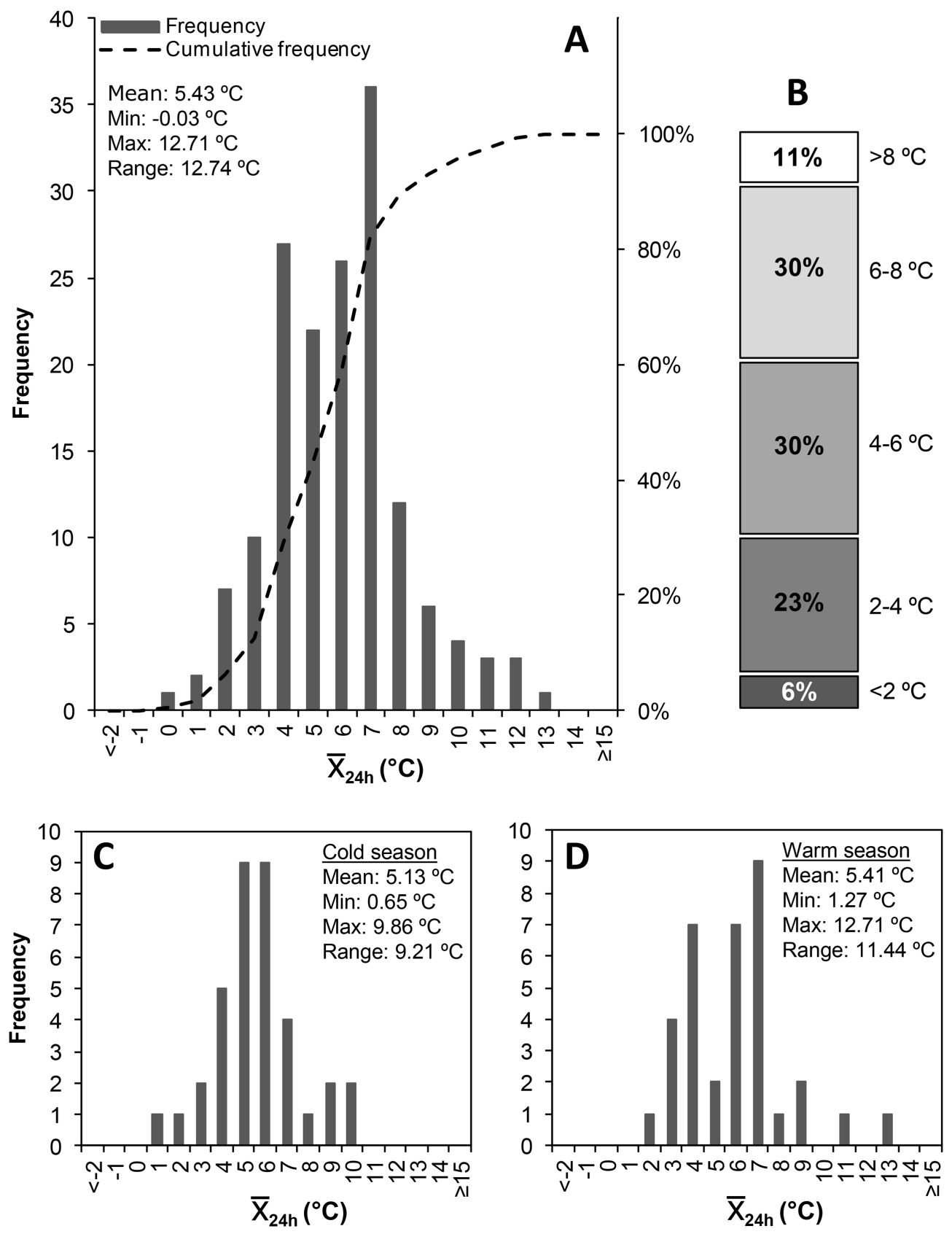


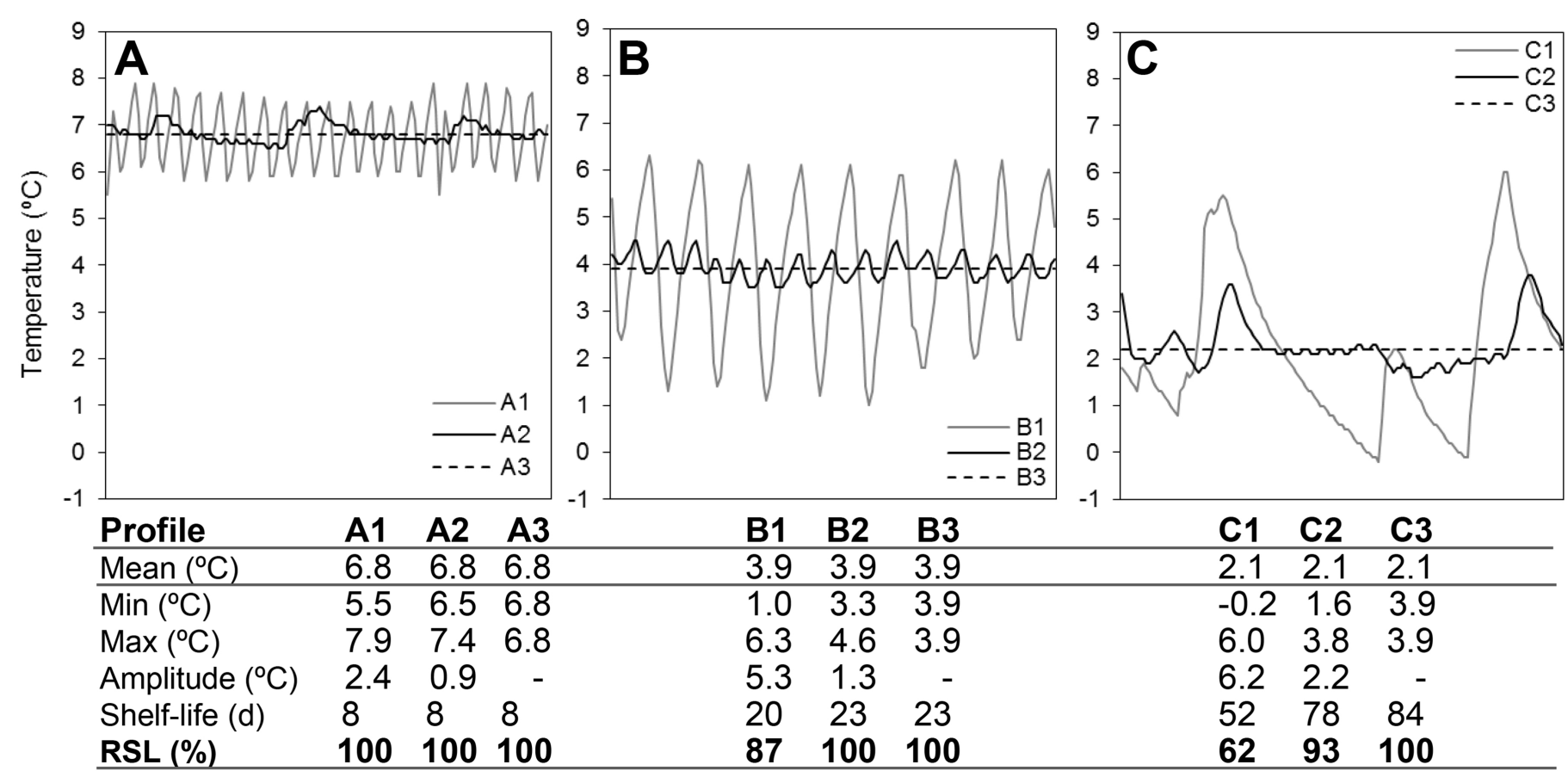

